\title{
ВMJ Global Health Intellectual property rights need to be subverted to ensure global vaccine access
}

\author{
Salla Sariola
}

To cite: Sariola S Intellectual property rights need to be subverted to ensure global vaccine access. BMJ Global Health 2021;6:e005656. doi:10.1136/ bmjgh-2021-005656

Handling editor Seye Abimbola

Received 9 March 2021

Revised 17 March 2021

Accepted 18 March 2021
Check for updates

(C) Author(s) (or their employer(s)) 2021. Re-use permitted under CC BY-NC. No commercial re-use. See rights and permissions. Published by BMJ.

Department of Social Sciences, Sociology, University of Helsinki, Helsinki, Finland

Correspondence to

Dr Salla Sariola;

salla.sariola@helsinki.fi
A commentary by Murphy and colleagues, ${ }^{1}$ published in BMJ Global Health on the 19 February 2021, brings attention to the unprecedented efforts for COVID-19 vaccine discovery and asks if the world could learn from this example to better facilitate access to medicines in low-income and middle-income countries (LMICs).

My response to their comment claims that though well intended and to the point, the commentary misses a crucial bottleneck in research and development, namely, intellectual property rights (IPRs) that hinder the actualisation of global vaccine access.

Instead of making vaccine knowledge available openly, IPRs protect industry benefits over human health and well-being. The current arrangement is epidemiologically short-sighted and unjust. The brunt of vaccine capitalism is felt most in LMICs and Africa in particular. $^{2}$

Presently, philanthropic programmes to deliver vaccines to LMICs are not fast enough, and a social movement is picking up speed to subvert IPRs that are upheld by rich countries at the World Trade Organization (WTO). Global health communities need to take a stronger stance against IPRs that are protecting vaccine pharma over the world's poorest and leverage political will to make global vaccine access a reality.

\section{HOW PATENT REGULATION FRAMES VACCINE ACCESS}

IPRs block global vaccine access in three ways.

First, IPRs legitimate the pharmaceutical industry to make exclusive decisions to whom vaccines are sold and at what price. Under the Trade Related Intellectual Property Rights Agreement (TRIPS) by WTO, companies that own the intellectual property hold exclusive rights to produce vaccines without competing generic products on the market. This way, they are able to keep a foothold

\section{Summary box}

- Vaccine access is essential for building global immunity against COVID-19, and presently, lowincome and middle-income countries (LMICs) are facing considerable barriers for access.

- Intellectual property rights (IPRs) are a crucial obstacle for global vaccine access.

- Instead of making vaccines available openly, IPRs protect industry profits over human health and well-being.

- Philanthropic programmes are not delivering vaccines to LMICs fast enough and distort the role of IPRs at the heart of access injustice.

- An international movement to waive IPRs of COVID-19 vaccines is gaining support globally, but rich countries at the World Trade Organisation are opposing.

- Global health scholars need to join the pressure to realise global vaccine access.

of the markets and the prices high, as there is little competition over similar products. Vaccines currently on the market have been priced such that developing countries cannot afford them. Prices may also vary depending on the contract: for example, contradictory to a social justice logic, the AstraZeneca vaccine was sold to South Africa at $\$ 5.25$ per dose but to $\mathrm{EU}$ at a lower rate of $\$ 2.16$. $^{3}$

The second reason follows from the first. Availability of vaccines at national level is made possible via bilateral prepurchase agreements between vaccine producers and countries or regions, such as the European Union or the African Union. The African Union, with the help of the African ExportImport Bank, has negotiated an agreement to prefinance 670 million doses of vaccines while African countries pool their funds, ${ }^{4}$ but still, very few low-income countries have contracts that would provide sufficient volumes to cover their entire populations. ${ }^{56}$ In short, different countries are not on an equal footing on 
funding and networks in the negotiations, and the African Union has been a low priority.

Third, the COVAX programme was established in April 2020 to ensure that vaccines spread globally at equal pace after their licencing approval. COVAX is often lauded as a mechanism that holds promise for just vaccine access, but its public representation is glossier than the reality. COVAX is funded by various philanthropic funders and wealthy countries; it aims to cover $20 \%$ of populations in countries that have funded it and to provide 1 billion doses across 92 non-funding lower income countries. ${ }^{4}$ In December 2020, COVAX was close to failure due to insufficient funding, ${ }^{7}$ but one of the first decisions by President Joe Biden's new administration was to give its support to COVAX, ${ }^{8}$ which improved its chances of success. Simultaneously, rich countries such as Canada have grabbed vaccines through the COVAX programme. ${ }^{9}$ Canada has five times the number of vaccines required to cover its entire population. ${ }^{10}$ Due to the reality of manufacturing rates, the surplus of some is at the expense of others, which brings to a sharp focus the inherent inequality in how access is shaped by the purchasing power of countries where people happen to be born. While the COVAX programme has commenced vaccinations for frontline carers in several lower income countries during February and March 2021, the majority of the populations in these countries have no vaccines in sight. The dynamic underscores how COVAX is unable to remove global vaccine injustices and at worst reproduces differences between the haves and the have-nots with a seeming guise of 'doing something about it'.

\section{RESISTANCE TO PATENT WAIVERS}

While COVAX is notable in its charitable efforts, it remains a smokescreen for the IPRs issue at the heart of the inequity of vaccine deployment. India and South Africa proposed to the World Trade Organization in October 2020 that a waiver of IPRs should be mandated to guarantee international availability of vaccines under the exceptional pandemic circumstances. ${ }^{11}$

The proposed waiver would see various aspects of the TRIPS agreement surrendered, denying pharmaceutical companies exclusive rights to produce vaccines and benefit from their sales. The waiver would not only forego patents but various other aspects of IPR, such as trade secrets, copyright, manufacturing knowhow, industrial design, blueprints and so on, that might get in the way of universal production. The motion is presently cosponsored or supported by 100 countries from two key groups at WTO: the Africa Group and the Least Developed Countries Group. ${ }^{12}$ These are also the countries where vaccine gaps are felt most.

The waiver has so far not been accepted by the WTO. European Union, USA, UK, South Korea, Japan, Switzerland, Canada, Brazil, Australia and Mexico continued to oppose the waiver in the most recent WTO meeting on 10 March $2021 .^{13} 14$ The rationale by big pharma and countries that stand beside them ultimately protects the interests of big pharma and its profit-based logic rather than the public. The proposed waiver is time bound and restricted to products related to the pandemic but a more radical reformation could have profound impacts in how innovation is organised in the future by questioning the capitalist modus operandi of vaccine production.

\section{LEARNING FROM THE PAST}

Waiving patents is not a radical or new proposal. The most notable example is the use of compulsory licencing for cheap antiretrovirals in early 2000s. A social movement led by the South African NGO Treatment Action Campaign sued the South African government over the denial of its citizens' health rights and mobilised the Indian generic pharmaceutical company Cipla to produce cheap generics. The price of antiretroviral medication (ARVs) was reduced by $97 \%$, and with this, the HIV epidemic in Africa has been brought under control. $^{15}$

The campaign is not unique in its purpose: compulsory licencing is regularly applied in various situations, of which epidemics are just one. However, since the 2000s, stronger patent barriers have been established, making it harder to subvert patents. Compulsory licencing is not seen sufficient and timely enough for COVID-19 vaccines: it is slow because it requires separate negotiations between countries and companies, would not provide access to key elements in production such as trade secrets, it maintains barriers for collaboration and import and export of products and materials and does not cover future vaccines. The waiver would remove any obstacles for global vaccine production, present and future. However, in the light of the opposition, it seems that without a strong international movement and direct pressure, similar motion is unlikely. Organisations like Medicines Sans Frontiers, People's Vaccine Alliance, Third World Network and the European United Left at European Parliament have advocated the waiver, and it is time that global health scholars worldwide stand with them.

\section{CONCLUSIONS}

Arguments to defend IPRs simply do not hold. The commonly presented claim that IPRs protect innovator companies from market failure and financial risks do not apply in case of COVID-19 vaccines because the research was done predominantly on public funding from various governments in the Global North ${ }^{16}$ which means that companies had to invest very little, and there continues to be an enormous market for vaccines. COVID-19 vaccines should be treated as global public goods because at present, the protections of IPRs to the vaccine companies are causing health and socioeconomic suffering globally, rather than alleviating them.

Delaying vaccine access for billions of people threatens the continuation of the pandemic and development of 
further mutations. Global health communities need to join the motion and put pressure on the WTO for when the waiver is discussed at the upcoming WTO meetings during the spring, lest allowing vaccine capitalism and apartheid to endure.

\section{Twitter Salla Sariola @SallaSariola}

Contributors I am the sole author of this work.

Funding This study was funded by Academy of Finland (316941).

Competing interests None declared.

Patient consent for publication Not required.

Provenance and peer review Not commissioned; internally peer reviewed.

Data availability statement There are no data in this work.

Open access This is an open access article distributed in accordance with the Creative Commons Attribution Non Commercial (CC BY-NC 4.0) license, which permits others to distribute, remix, adapt, build upon this work non-commercially, and license their derivative works on different terms, provided the original work is properly cited, appropriate credit is given, any changes made indicated, and the use is non-commercial. See: http://creativecommons.org/licenses/by-nc/4.0/.

ORCID iD

Salla Sariola http://orcid.org/0000-0003-3401-7727

\section{REFERENCES}

1 Murphy A, Mbau L, McKee M, et al. Can we do for other essential medicines what we are doing for the COVID-19 vaccine? BMJ Glob Health 2021;6:e005158.

2 Boum li Y, Ouattara A, Torreele E, et al. How to ensure a needsdriven and community-centred vaccination strategy for COVID-19 in Africa. BMJ Glob Health 2021;6:e005306.

3 Sullivan $\mathrm{H}$. South Africa paying more than double EU price for Oxford vaccine. guardian, 2021. Available: https://www.theguardian. $\mathrm{com} /$ world/2021/jan/22/south-africa-paying-more-than-double-euprice-for-oxford-astrazeneca-vaccine

4 Berkeley S. The Gavi COVAX AMC explained. Gavi vaccine alliance, 2021. Available: https://www.gavi.org/vaccineswork/gavi-covaxamc-explained [Accessed 15 Mar 2021].

5 Asala K. Egypt Begins its COVID-19 Vaccination Campaign with China's Sinopharm. Africa News, 2021. Available: https://www. africanews.com/2021/01/25/egypt-begins-its-covid-19-vaccinationcampaign-with-china-s-sinopharm/ [Accessed 3 Mar 2021].

6 Africa News. Morocco kicks off coronavirus vaccination drive, 2021. Available: https://www.africanews.com/2021/01/28/morocco-kicksoff-coronavirus-vaccination-drive/ [Accessed 2 Mar 2021].

7 World Health Organisation. COVAX expects to start sending millions of COVID-19 vaccines to Africa in February, 2021. Available: https:// www.afro.who.int/news/covax-expects-start-sending-millions-covid19-vaccines-africa-february

8 Schuster-Bruce C. Fauci confirms that Biden will remain in the WHO and join its vaccine scheme, COVAX, which Trump claimed was 'China-centric' and refused to be a part of. Insider, 2021. Available: https://www.businessinsider.com/biden-join-who-world-healthorganization-covax-vaccine-trump-2021-1? $r=U S \& I R=T$ [Accessed 2 Mar 2021].

9 Cecco L. 'We're double-dipping': Trudeau pressured to speed vaccine distribution amid Covax backlash. The Guardian, 2021 Available: https://www.theguardian.com/global-development/2021/ $\mathrm{feb} / 09 /$ canada-coronavirus-vaccine-covax-trudeau

10 Gill P. Canada has enough COVID-19 vaccine doses to cover each citizen five times over while the fate of 67 poor countries remains undecided. bus insider India, 2021. Available: https://www. businessinsider.in/science/health/news/canada-has-enough-covid19-vaccine-doses-to-cover-each-citizen-five-times-over-whilethe-fate-of-67-poor-countries-remains-undecided/articleshow/ 79645493.cms [Accessed 3 Mar 2021].

11 World Trade Organisation. Waiver from certain provisions of the TRIPS agreement for the prevention, containment and treatment of COVID-19: communication from India and South Africa IP/C/W/669, 2020. Available: https://docs.wto.org/dol2fe/Pages/SS/directdoc. aspx?filename=q:/IP/C/W669.pdf\&Open=True

12 Medicines Sans Frontiers. Map showing which countries support or oppose the Covid IP Waiver at WTO, 2021. Available: https:// www.google.com/maps/d/u/0/viewer?mid=1ziXSn04hdvXwSET XTMPUcwM07cTEDFhC\& $\|=44.756038204179646 \% 2 C-33$. $8326761398514 \& z=2$ [Accessed 3 Mar 2021].

13 Kanth RD. Developing countries call for textbased negotiations on TRIPS waiver. Third World Econ 2021;716:4-6.

14 Oxfam. Rich countries block COVID-19 vaccines waiver at World Trade Organization - Oxfam reaction, 2021. Available: https:// www.oxfam.org/en/press-releases/rich-countries-block-covid-19vaccines-waiver-world-trade-organization-oxfam [Accessed 15 Mar 2021].

15 Hoen Ellen 't, Berger J, Calmy A, et al. Driving a decade of change: HIV/AIDS, patents and access to medicines for all. J Int AIDS Soc $2011 ; 14: 15$

16 Medicines Sans Frontiers. Governments must demand pharma make all COVID-19 vaccine deals public, 2020. Available: https://www.msf org/governments-must-demand-all-coronavirus-covid-19-vaccinedeals-are-made-public [Accessed 15 Mar 2021] 